\title{
Biochar association with phosphate fertilizer and its influence on phosphorus use efficiency by maize
}

\author{
Associação de biocarvão com fertilizante fosfatado e sua influência na \\ eficiência de uso do fósforo pelo milho
}

\author{
Sara Ramos dos Santos ${ }^{1}$ (D) José Ferreira Lustosa Filho (iD), \\ Leonardus Vergütz ${ }^{3}$ (D), Leônidas Carrijo Azevedo Melo ${ }^{2 *}$ (iD
}

\author{
1Universidade de São Paulo/USP, Escola Superior de Agricultura Luiz de Queiroz/ESALQ, Piracicaba, SP, Brasil \\ 2Universidade Federal de Lavras/UFLA, Departamento de Ciência do Solo/DCS, Lavras, MG, Brasil \\ 3Universidade Federal de Viçosa/UFV, Departamento de Solos/DPS, Viçosa, MG, Brasil \\ ${ }^{*}$ Corresponding author: leonidas.melo@ufla.br \\ Received in November 7, 2018 and approved in January 28, 2019
}

\begin{abstract}
The use of fertilizers with some degree of protection of the phosphate ions can reduce soil adsorption and increase the absorption by plants, increasing the efficiency of phosphorus $(P)$ fertilization. This study aimed to evaluate the performance of a phosphate fertilizer associated with biochar in granules in a P-fixing soil in a greenhouse experiment. Biochars were produced from two sources of biomass: sugarcane bagasse (SB) and wood sawdust (WS), which were pyrolysed at two temperatures $\left(350^{\circ} \mathrm{C}\right.$ and $\left.700^{\circ} \mathrm{C}\right)$. After chemical and physical characterization, the biochar samples were granulated with triple superphosphate (TSP) in a 3:1 ratio (TSP: biochar). The agronomic evaluation of the fertilizers was carried out by two successive maize crops (Zea mays L.) in the greenhouse, using a factorial scheme of (5x3) in randomized block design with four replicates. The treatments consisted of five fertilizers (TSP-WS ${ }_{350^{\prime}}$ TSP-WS ${ }_{700^{\prime}}$, TSP-SB $_{350^{\prime}}$ TSP-SB $_{700^{\prime}}$ and TSP) and three P doses (100, 200 , and $400 \mathrm{mg} \mathrm{dm}^{-3}$ ). It was evaluated the dry matter production, $\mathrm{P}$ uptake in maize and $\mathrm{P}$ available in the soil after cultivation. The results indicate that dry matter production, considering the $\mathrm{P}$ uptake by the plant and the $\mathrm{P}$ available in the soil when using a dose of $400 \mathrm{mg}$ $\mathrm{dm}^{-3}$, presented higher results in both crop cycles and the recovery rate in both cultivations occurred inversely to the $P$ doses. The simple association of biochar with soluble phosphate fertilizer did not increase the efficiency of P use by maize, but it increased available P in soil.
\end{abstract}

Index terms: Organic residues; adsorption; pyrolysis; tropical soils.

\section{RESUMO}

O uso de fertilizantes com alguma proteção aos íons fosfato pode diminuir sua adsorção pelo solo e aumentar a absorção pela cultura, o que aumenta a eficiência da adubação. O objetivo deste trabalho foi avaliar o desempenho de um fertilizante fosfatado associado a biocarvão em um solo com alta capacidade de fixação de P. Os biocarvões foram produzidos a partir de duas fontes de biomassa: bagaço de cana-de-açúcar (BC) e serragem de madeira (SM), as quais foram pirolisadas em duas temperaturas $\left(350^{\circ} \mathrm{C}\right.$ e $\left.700{ }^{\circ} \mathrm{C}\right)$. Após a caracterização química e física, os biocarvões foram granulados com superfosfato triplo (TSP) em uma proporção 3:1 (TSP: biocarvão). A avaliação agronômica dos fertilizantes foi realizada por dois cultivos sucessivos de milho (Zea mays L.) em casa de vegetação em Latossolo argiloso em esquema fatorial (5×3) em delineamento de blocos inteiramente casualizados com 4 repetições. Os tratamentos consistiram de cinco fertilizantes (TSP-SM ${ }_{350}$, TSP-SM $_{700}$, TSP-BC $_{350}$, TSP-BC $_{700}$ and TSP) e três doses de P (100, 200 e $400 \mathrm{mg} \mathrm{dm}^{-3}$ de P). Foram avaliados a produção de massa de matéria seca, acúmulo de $\mathrm{P}$ no milho, além do $\mathrm{P}$ disponível no solo após os cultivos. A produção de matéria seca, conteúdo de P na planta e P disponível no solo apresentou resultados superiores em ambos os cultivos na dose de $400 \mathrm{mg} \mathrm{dm}^{-3}$, já a taxa de recuperação aumentou de forma inversa em relação as doses. A simples associação de biocarvão com fertilizante fosfatado solúvel não aumentou a eficiência de uso de P pelo milho, mas aumentou o P disponível no solo após dois cultivos sucessivos.

Termos para indexação: Resíduos orgânicos; adsorção; pirólise; solos tropicais.

\section{INTRODUCTION}

Phosphate fertilizers are mainly produced from phosphate rocks (PR), which are non-renewable and finite source materials. Existing PR reserves are expected to deplete in the next 50-100 years (Cordell; Drangert; White,
2009). Additionally, only $15-30 \%$ of $P$ applied in soils via fertilizer is taken up by crops in the first year of application (Syers; Johnston; Curtin, 2008). Such situation of low P use efficiency can become even worst in weathered soils from humid tropical regions due to the strong interaction 
of phosphate anions $\left(\mathrm{H}_{2} \mathrm{PO}_{4}^{-}\right.$and $\left.\mathrm{HPO}_{4}^{2-}\right)$ with iron and aluminum oxyhydroxides, leading to $\mathrm{P}$-fixation over time (Abdala et al., 2015; Bolan; Barrow; Posner, 1985; Novais; Smyth, 1999). Therefore, increase of $P$ use efficiency by crops is needed and can be achieved by improved P-acquisition efficiency and by P-use efficiency (Veneklaas et al., 2012), which relies on $P$ availability in soils.

Acidulated PR are the most used sources for fertilizer production, which release $\mathrm{P}$ very fast (Chien; Prochnow; Cantarella, 2009), causing sorption on soil particles and, consequently, reducing $\mathrm{P}$ uptake and the effectiveness of P fertilizer application (Kang et al., 2011). Recently, new technologies of phosphate fertilizer have been developed in order to enhance P use efficiency in soils, such as the incorporation of humic substances (Erro et al., 2016), coating with polymers (Sanders et al., 2012; Guelfi et al., 2018), pelletization or granulation with biochar (Kim; Hensley; Labbé, 2014), and pretreating or post-treating the biochar to produce enhanced biochar-based fertilizers (Yao et al., 2015; Lustosa Filho et al., 2017).

Biochar is the solid material of pyrolysed biomass under low or no oxygen environment (Lehmann; Stephen, 2015; Placido; Capareda; Karthikeyan, 2016). Biochar application to soil has been shown to increase $P$ availability due to reduction of $\mathrm{P}$ adsorption on Fe-oxides (Cui et al., 2011) or due to both $P$ adsorption reduction and $P$ direct supply, acting as a $\mathrm{P}$ source at application rates as high as $8 \%$ by weight (Parvage et al., 2013; Zhai et al., 2015). However, such high rates of biochar as a soil amendment are unfeasible at large scale field application due to uncertain increase in crop yield (Liu et al., 2013). In a field experiment under temperate climate, it was demonstrated that low biochar amounts $\left(1.0 \mathrm{tha}^{-1}\right)$ combined with mineral fertilizer had better performance when compared to pure fertilizers (Glaser et al., 2015). However, granulation of biochar with phosphate fertilizer for application in tropical soils has never been tested so far. Thus, we hypothesized that the association of water-soluble phosphate fertilizer with biochar could improve plant $\mathrm{P}$ uptake and use. The objective of this study was to evaluate the performance of a phosphate fertilizer associated with biochar in granules in a P-fixing soil in a greenhouse experiment.

\section{MATERIAL AND METHODS}

\section{Feedstock and biochar production}

Wood sawdust (WS) was collected in a sawmill and it is composed of a mix of wood of different species.
Sugarcane bagasse (SB) was collected in a sugarcane power plant facility located at the following coordinates: latitude: $20^{\circ} 18^{\prime} 5^{\prime \prime} \mathrm{S}$; longitude: $42^{\circ} 41^{\prime} 26^{\prime \prime} \mathrm{W}$. The biomasses were chosen due to their large availability in Brazil and contrasting characteristics in terms of nutrients, cellulose, and lignin contents. After being oven-dried to constant weight at $75^{\circ} \mathrm{C}$ for $72 \mathrm{~h}$, the biomasses were ground to less than $2 \mathrm{~mm}$ and then subjected to a typical slow pyrolysis process for biochar production as described elsewhere (Lustosa Filho et al., 2017). Briefly, the ground biomass was placed in a muffle furnace, and pyrolysis was performed by raising the temperature up to $350{ }^{\circ} \mathrm{C}$ and $700{ }^{\circ} \mathrm{C}$ at a heating rate of $10{ }^{\circ} \mathrm{C} \mathrm{min}^{-1}$, maintaining the target temperature for $1 \mathrm{~h}$ to provide enough time for complete carbonization. The resulting biochars were allowed to cool to room temperature. The biochar yield was calculated using the following equation:

Yield $(\%)=\left[\frac{W_{f}}{W_{0}}\right] x 100$

where $W f$ is the dry mass ( $\mathrm{g}$ ) of the produced biochars and $W_{0}$ is the dry mass $(\mathrm{g})$ of the feedstock.

The produced biochars were identified as: $\mathrm{WS}_{350}$ : wood sawdust pyrolysed at $350^{\circ} \mathrm{C}$; $\mathrm{WS}_{700}$ : wood sawdust pyrolysed at $700^{\circ} \mathrm{C} ; \mathrm{SB}_{350}$ : sugarcane bagasse pyrolysed at $350{ }^{\circ} \mathrm{C}$; and $\mathrm{SB}_{700}$ : sugarcane bagasse pyrolysed at $700^{\circ} \mathrm{C}$.

\section{Characterization of the biochars}

The $\mathrm{pH}$ and the electrical conductivity (EC) were measured in deionized water at 1:10 biochar: water ratio, after 30 min of shaking (Singh; Singh; Cowie, 2010). The total carbon $(\mathrm{C})$, hydrogen $(\mathrm{H})$, and nitrogen $(\mathrm{N})$ contents of the biochars were determined by dry combustion at $950{ }^{\circ} \mathrm{C}$ using an automatic elemental analyzer (Jasco FTIR 4100). The ash contents of the biochars were evaluated by the standard method NBR 8112 (ASTM, 2007). Approximately $2.0 \mathrm{~g}$ of oven-dried biochar samples were heated in an open crucible at $750{ }^{\circ} \mathrm{C}$ for 6 hours. The samples were cooled down, weighed, and the percentage of ash content was calculated as follows:

$$
\operatorname{Ash}(\%)=\left[\frac{\text { remaining solids } w t(g)}{\text { original biochar } w t(g)}\right] x 100
$$

Bulk density was determined using the method described in Ahmedna et al. (1997). A 10-mL cylinder 
was filled to a specified volume with powdered biochar sample that had been oven dried at $80{ }^{\circ} \mathrm{C}$ overnight. The pre-weighted cylinder was tapped for at least 1-2 min to compact the biochar and weighed. The bulk density was then calculated by the following formula:

Bulk density $\left(\frac{\mathrm{g}}{\mathrm{cm}^{3}}\right)=\left[\frac{\text { Weight of dry sample }(\mathrm{g})}{\text { Volume of packed dry material }\left(\mathrm{cm}^{3}\right)}\right]$

The cation exchange capacities (CEC) of the biochar samples were measured by a modified Ammonium Acetate compulsory displacement method (Gaskin et al., 2008). Briefly, $0.5 \mathrm{~g}$ of biochars was weighed and placed in a suitable vacuum-filtering carrier containing a $0.45-\mu \mathrm{m}$ filter. Biochar samples were washed with 20 $\mathrm{mL}$ of deionized water five times to remove soluble ions. The biochars were passed with five portions of $20 \mathrm{~mL}$ of sodium acetate $\left(1.0 \mathrm{~mol} \mathrm{~L}^{-1}, \mathrm{pH} 7\right)$ and were then washed three times with $20 \mathrm{~mL}$ of ethanol to remove excessive $\mathrm{Na}^{+} . \mathrm{Na}^{+}$on the exchangeable sites of the biochars was displaced by three portions of $20 \mathrm{~mL}$ of ammonium acetate (1.0 $\left.\mathrm{mol} \mathrm{L}^{-1}, \mathrm{pH} 7\right)$, collecting the filtrate and completing to $250 \mathrm{~mL}$ to further analyze by flame photometry (DigimedDM 62). A blank sample was also included. The CEC of the biochars was calculated from the $\mathrm{Na}^{+}$displaced by $\mathrm{NH}_{4}^{+}$according to the used sample mass.

Total $\mathrm{P}$ content was determined by extraction with $1.0 \mathrm{~mol} \mathrm{~L}^{-1} \mathrm{HCl}$ from the ashes after heating at $250{ }^{\circ} \mathrm{C}$ for two hours. In the obtained extract, levels of $\mathrm{P}$ were quantified by Inductively Coupled Plasma Optical Emission Spectrometry (ICP-OES) (Miller, 1998).

The functional groups present in the powdered biochar samples were investigated by Fourier transform infrared spectroscopy (FTIR) in ATR mode (Jasco FTIR 4100 ) in the range of 4000-400 $\mathrm{cm}^{-1}$ at a resolution of 4 $\mathrm{cm}^{-1}$ with an average of 32 scans.

\section{Granules preparation}

Phosphate fertilizers were prepared by granulation of triple superphosphate (TSP) with the biochars previously described. Cassava starch (4\%) was used as a binding agent to promote the hardness of fertilizers granules containing biochar. TSP was homogenized with each biochar in the proportion of $70 \%$ (fertilizer) $+30 \%$ (biochar). Deionized water was added to the dry mixture and homogenized until it had pasty consistency (moldable), which then was placed in a stainless steel pastillator with circular holes of 5.0 $\mathrm{mm}$ in diameter and $3.0 \mathrm{~mm}$ in height. The material was manually accommodated until all holes in the plate were filled (200 total), and the wet granules were suspended of the pastillator. The set was placed in an oven to dry at $65{ }^{\circ} \mathrm{C}$ until constant weight. For the preparation of TSP without biochar, distilled water and cassava starch (4\%) were added using the same procedure described above. The contents of total $\mathrm{P}$ and water soluble $\mathrm{P}$ were determined for all fertilizers before their application to the soil (Brasil, 2014). The $P$ content was quantified according to the molybdenum yellow method.

\section{Greenhouse experiment with maize}

The experiment was carried out under greenhouse conditions aiming at evaluating the agronomic efficiency of the granulation of TSP with the biochars. Samples of a clayey Oxisol (Typic Hapludox) with high adsorption capacity of P (P-rem $\left.<15 \mathrm{mg} \mathrm{L}^{-1}\right)$ were collected from the 0-20 cm layer. Soil samples were air-dried and passed through a 4-mm sieve for the experiment and through a 2-mm sieve for chemical and physical characterization (Table 1). Soil samples were placed into plastic bags (4.0 $\left.\mathrm{dm}^{3}\right)$ and lime $\left(\mathrm{CaCO}_{3}\right.$ and $\mathrm{MgCO}_{3}$ p.a., 3:1 molar ratio) was mixed aiming to raise the soil base saturation to $70 \%$. The soil was incubated for 30 days with the carbonates, keeping the moisture at around $70 \%$ of the field capacity water retention. Thereafter, the soil was air-dried, homogenized, and fertilized with the following nutrients: $\mathrm{N}, \mathrm{K}, \mathrm{S}, \mathrm{Zn}, \mathrm{Mn}, \mathrm{Fe}, \mathrm{Cu}, \mathrm{B}$, and $\mathrm{Mo}$, which were applied at the rates of $100,100,40,4.0,3.66,1.55,1.33,0.81$, and $0.15 \mathrm{mg} \mathrm{dm}^{-3}$, respectively (Novais; Neves; Barros, 1991).

Treatments were arranged in a factorial design $(5 \times 3)+1$, being five P sources $\left(\mathrm{TSP}-\mathrm{WS}_{350}, \mathrm{TSP}-\mathrm{WS}_{700}\right.$, TSP-SB ${ }_{350}, \mathrm{TSP}_{-} \mathrm{SB}_{700}$ and TSP) that were evaluated at three $\mathrm{P}$ rates $\left(100,200\right.$, and $\left.400 \mathrm{mg} \mathrm{dm}^{-3}\right)$. A control, without $P$ application, was also included. The experiment was carried out in a randomized block design with four replications. The fertilizers were homogeneously applied in the entire volume of soil in pre-cultivation.

Five seeds of maize (Zea mays) were sown in each pot containing $4.0 \mathrm{dm}^{3}$ of soil and thinned after seven days to three plants, which were grown during 40 days. Nitrogen and potassium fertilizations were applied at 5 and 15 days after seeding using a solution, aiming to reach $100 \mathrm{mg} \mathrm{dm}^{-3}$ each time. In order to evaluate the residual effect of the fertilizers, another successive maize crop was carried out, with a 30 days interval between cropping. In the second crop, the same fertilization of the first cultivation was applied, with the exception of the P sources. The moisture of pots was maintained at nearly $70 \%$ of field capacity and replacement was done daily using distilled water, according to plant demand throughout the experimental period. 
Table 1: Chemical characterization of the soil.

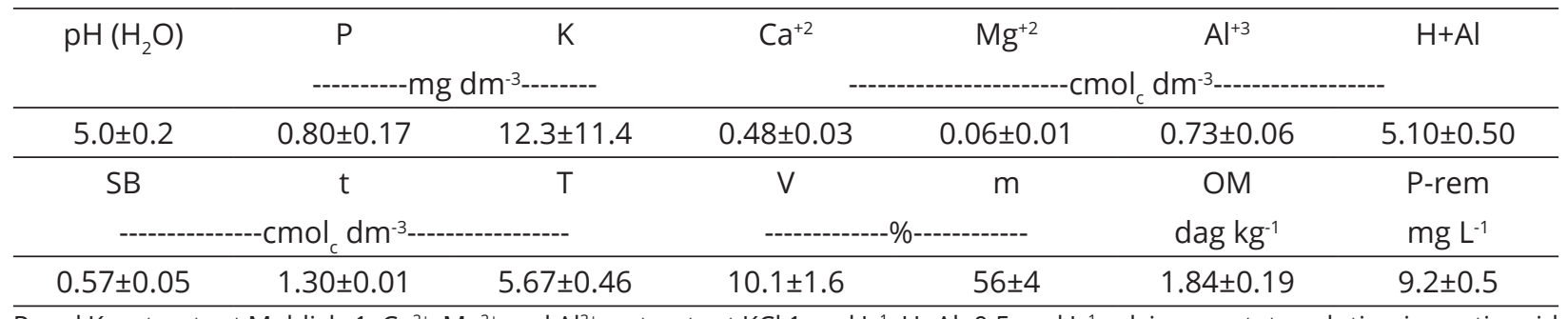

$\mathrm{P}$ and $\mathrm{K}$ : extractant Mehlich-1; $\mathrm{Ca}^{2+}, \mathrm{Mg}^{2+}$ and $\mathrm{Al}^{3+}$ : extractant $\mathrm{KCl} 1 \mathrm{~mol} \mathrm{~L}^{-1} ; \mathrm{H}+\mathrm{Al}-0.5 \mathrm{~mol} \mathrm{~L}^{-1}$ calcium acetate solution in acetic acid at pH 7.0 (Donagema et al., 2011); SB: sum of bases; (t): effective cation exchange capacity; (T): cation exchange capacity at pH 7; $\mathrm{V}$ : base saturation; m: aluminum saturation; OM: organic matter, oxidation of $\mathrm{Na}_{2} \mathrm{Cr}_{2} \mathrm{O}_{7} 0.67 \mathrm{~mol} \mathrm{~L}^{-1}+\mathrm{H}_{2} \mathrm{SO}_{4} 5 \mathrm{~mol} \mathrm{~L}^{-1}$ (Donagema et al., 2011). Remaining P (P-rem) (Alvarez et al., 2000). Values are mean $(n=3) \pm$ standard deviation.

After 40 days, the plants were harvested, washed with deionized water, dried in an oven at $65{ }^{\circ} \mathrm{C}$ until weight stabilization $(\approx 72 \mathrm{~h}$ ), analyzed for yield (dry matter production) and then milled for chemical analysis. Shoot tissues were digested in a block digestion system using concentrated nitric-perchloric solution, and P contents were measured colorimetrically, following analytical procedures as described in Malavolta, Vitti and Oliveira (1997). Uptake of $\mathrm{P}$ in maize shoot was estimated by multiplying the $\mathrm{P}$ content with the respective dry matter yield. After the second cultivation, soil available P was extracted by the Mehlich-1 method and determined by the colorimetric ascorbic acid method, according to Braga and Defelipo (1974).

The relative agronomic effectiveness (RAE), which shows the increase in yield due to each unit of $\mathrm{P}$ applied, was evaluated for each of the two successive crops and calculated by the following equation:

$R A E(\%)=\frac{(P i-P 0)}{\left(P_{t s p}-P 0\right)} \times 100$

in which Pi is the dry matter production by plants in a given treatment $\left(\mathrm{g} \mathrm{plant}^{-1}\right)$; $\mathrm{P} 0$ is the dry matter production by plants in the control treatment without $\mathrm{P}$ application; $\mathrm{P}_{\text {tsp }}$ is the dry matter production by plants in the reference treatment (TSP).

Furthermore, the Recovery Rate of P (RR) was calculated by the equation bellow:

$R R p(\%)=\left[\frac{P \text { uptake in shoots in the treatments }-P \text { uptake in shoots in the control }}{\text { total } P \text { initially applied via fertilizer }}\right] x 100$

\section{Statistical analysis}

Data were subjected to analysis of variance (ANOVA) for significant differences among factors (P sources, $\mathrm{P}$ rates, and their interaction). For this analysis, however, the factorial scheme $5 \times 3$ (five fertilizers vs three doses of P) was adopted. Significant effects for treatments were detected using the $t$ test and when significant $(\mathrm{P}<0.05)$, the differences among treatments were analyzed by the Tukey test $(\mathrm{P}<0.05)$ (Ferreira, 2014).

\section{RESULTS AND DISCUSSION}

\section{Biochar characteristics}

The biochar yields were around $37 \%$ at $350{ }^{\circ} \mathrm{C}$ and $28 \%$ at $700{ }^{\circ} \mathrm{C}$ for both biomasses, indicating greater mass loss with increasing temperature. In addition, the increase of the pyrolysis temperature led to the increase of $\mathrm{pH}$ in the WS biochar (Table 2). The $\mathrm{pH}$ increase of the biochar with the increase of the pyrolysis temperature probably occurs due to the reduction of acidic functional groups (Li et al., 2017) and due to the formation of alkali compounds during pyrolysis (Domingues et al., 2017; Yuan; Xu; Zang, 2011).

The EC increased with an increase in pyrolysis temperature (Table 2) due to the higher ash content of these materials, which probably increases the dissolution of the water-soluble salts. Samples $\mathrm{SB}_{350}$ and $\mathrm{SB}_{700}$ presented lower density when compared to $\mathrm{WS}_{350}$ and $\mathrm{WS}_{700}$ due to the characteristics of the feedstock, since SB has lower density than WS. The ash contents in the biochars increased with increasing pyrolysis temperature due to the loss of volatile matter and concentration of the inorganic portion. The much higher ash content in the SB biochars than in the WS biochars is in agreement with other studies, which reported that plant biomass is much richer in nutrients than wood biomass (Domingues et al., 2017). 
Table 2: Basic properties of the produced biochars.

\begin{tabular}{ccccc}
\hline Properties & \multicolumn{4}{c}{ Biochar } \\
\cline { 2 - 5 } & $\mathrm{WS}_{350}$ & $\mathrm{WS}_{700}$ & $\mathrm{SB}_{350}$ & $\mathrm{SB}_{700}$ \\
\hline Yield (\%) & 36.6 & 28.5 & 37.0 & 28.4 \\
$\mathrm{pH}$ & $7.59 \pm 0.1$ & $9.67 \pm 0.1$ & $5.17 \pm 0.1$ & $9.06 \pm 0.1$ \\
$\mathrm{EC}\left(\mu \mathrm{cm}^{-1}\right)$ & $213 \pm 2.1$ & $504 \pm 5.0$ & $160 \pm 2.5$ & $330 \pm 5.5$ \\
Bulk density $\left(\mathrm{g} \mathrm{cm}^{-3}\right)$ & $0.44 \pm 0.0$ & $0.36 \pm 0.0$ & $0.19 \pm 0.0$ & $0.26 \pm 0.0$ \\
Ash (\%) & $4.25 \pm 0.4$ & $4.45 \pm 0.3$ & $23.3 \pm 0.4$ & $49.8 \pm 4.5$ \\
$\mathrm{CEC}\left(\mathrm{cmol}_{\mathrm{c}} \mathrm{kg}^{-1}\right)$ & $3.37 \pm 0.1$ & $1.65 \pm 0.4$ & $8.46 \pm 1.1$ & $5.81 \pm 1.6$ \\
$\mathrm{C}(\%)$ & 73.2 & 84.3 & 67.3 & 72.1 \\
$\mathrm{H} \mathrm{( \% )}$ & 2.2 & 0.2 & 2.3 & $\mathrm{ND}$ \\
$\mathrm{N} \mathrm{( \% )}$ & 0.2 & 0.3 & 0.3 & 0.4 \\
$\mathrm{P}\left(\mathrm{g} \mathrm{kg}^{-1}\right)$ & $0.53 \pm 0.1$ & $0.94 \pm 0.0$ & $2.65 \pm 0.2$ & $2.14 \pm 0.5$ \\
\hline
\end{tabular}

ND: not determined; WS-350: wood sawdust pyrolyzed at $350^{\circ} \mathrm{C} ;$ WS-700: wood sawdust pyrolyzed at $700^{\circ} \mathrm{C} ; \mathrm{SB}-350:$ sugarcane bagasse pyrolyzed at $350^{\circ} \mathrm{C}$ and SB-700: sugarcane bagasse pyrolyzed at $700^{\circ} \mathrm{C}$; EC: electrical conductivity; CEC: cation exchange capacity. Values are mean $(n=3) \pm$ standard deviation.

The SB biochars showed higher CEC than WS biochars for both pyrolysis temperatures and, within each biomass, there was a reduction of CEC with the increase of the temperature (Table 2), indicating a decrease in the oxygenated groups (e.g. carboxylic) responsible for the generation of negative charges. This result is in agreement with other authors who verified reduction in the CEC of biochars of different feedstock with the increase of the pyrolysis temperature (Song; Guo, 2012; Wu et al., 2012; Melo et al., 2013).

There was an increase in the $\mathrm{C}$ content and a reduction in the $\mathrm{H}$ content with increasing pyrolysis temperature (Table 2). This can be explained by the aromatization that these materials undergo with the pyrolysis, which is confirmed by the decrease of the $\mathrm{H} / \mathrm{C}$ ratio. The $\mathrm{N}$ content of the biochars were low, which might contribute to slow the decomposition of the biochar and reduce the emission of $\mathrm{N}_{2} \mathrm{O}$ from these materials into the environment (Lehmann; Gaunt; Rondon, 2006).

The FTIR spectra of the biochars, which provide information regarding the presence of several functional groups and chemical bonds on surface of the biochars, are shown in Figure 1. The spectra for the biochars obtained at the lower temperature of $350{ }^{\circ} \mathrm{C}$ was somewhat similar to temperature of $700{ }^{\circ} \mathrm{C}$, with the exception of $\mathrm{WS}_{350}$, which practically did not present peaks. At higher temperature, some peaks became more intense. The peaks around 3029 and $2125 \mathrm{~cm}^{-1}$ were assigned to aromatic $\mathrm{C}-\mathrm{H}$ stretches and aromatic ring summation bands
(Ghani et al., 2013), respectively. The peaks at 1755, 1592,1452 , and $1377 \mathrm{~cm}^{-1}$ are assigned, respectively, to $-\mathrm{OH}$ in plane bending modes and carbonyl $(\mathrm{C}=\mathrm{O}), \mathrm{C}=\mathrm{C}$ and $\mathrm{C}=\mathrm{O}$ of conjugated ketones and quinones, $\mathrm{C}=\mathrm{O}$ stretching vibration of carboxylate groups, and $-\mathrm{C}-\mathrm{H}_{2}$ bending (Cantrell et al., 2012; Chowdhury et al., 2016; Domingues et al., 2017; Ghani et al., 2013). The peak at $1452 \mathrm{~cm}^{-1}$, corresponding to $\mathrm{C}=\mathrm{O}$ stretching vibration of carboxylate groups, disappeared for the temperature of $700{ }^{\circ} \mathrm{C}$. Finally, the peak at $1222 \mathrm{~cm}^{-1}$ was attributed to $\mathrm{C}-\mathrm{O}$ stretching of lignin and hemicellulose (Phinichka; Kaenthong, 2017). With the increase in temperature, it was expected to detect the presence of more aromatic groups and a decrease in acidic groups (Singh; Singh; Cowie, 2010). However, the increase in temperature did not excluded the appearance of the peaks related to carboxylic acids, which were expected to be reduced to aromatic compounds.

\section{Greenhouse pot experiment}

The results of total and water-soluble $\mathrm{P}_{2} \mathrm{O}_{5}$ demonstrated that TSP showed high water solubility $(\approx 70 \%)$, which increased when it was associated with biochars (Table 3 ). This is an important indicator, since more soluble phosphate fertilizers are subject to higher sorption of $\mathrm{P}$ in highly weathered tropical soils, which reduces their use efficiency by plants (Novais; Smyth, 1999). The values of total $\mathrm{P}_{2} \mathrm{O}_{5}$ in the fertilizers associated with the biochars were lower due to the dilution effect. 


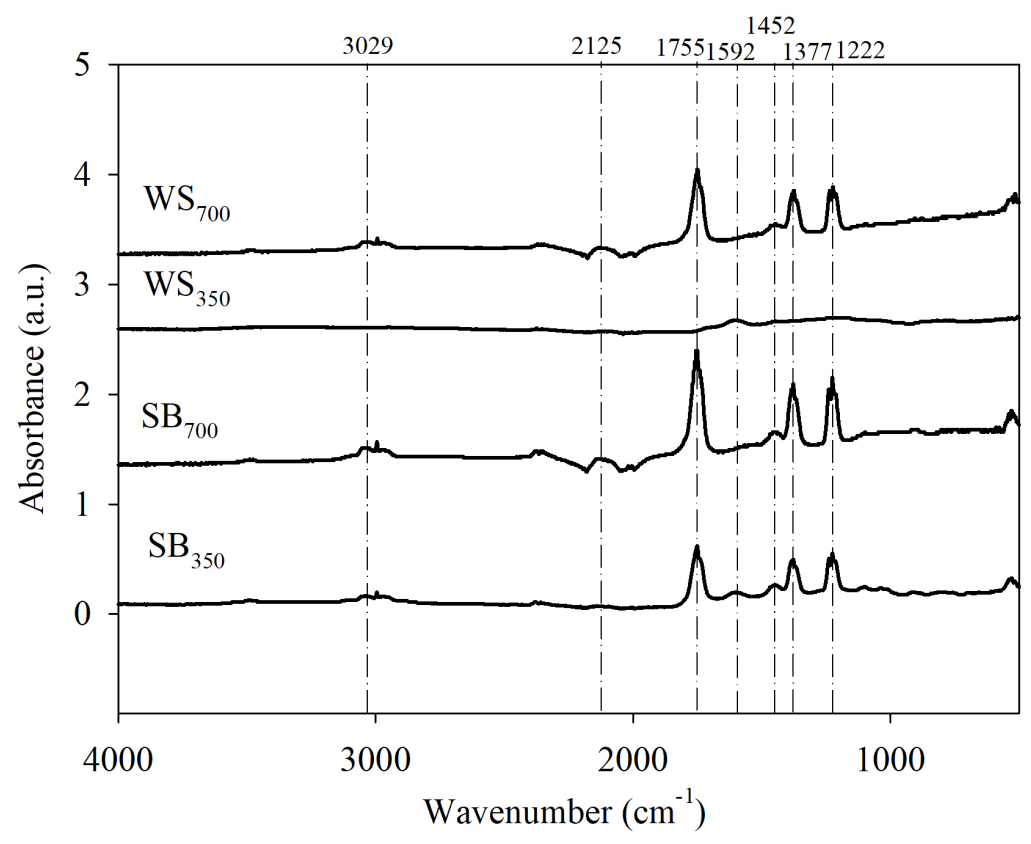

Figure 1: Fourier transform infrared spectroscopy (FTIR) spectra and key spectral bands of the produced biochars.

Table 3: Total and water soluble content of $\mathrm{P}_{2} \mathrm{O}_{5}$ in fertilizers.

\begin{tabular}{|c|c|c|c|}
\hline \multirow{2}{*}{ Fertilizer } & Total $\mathrm{P}_{2} \mathrm{O}_{5}$ & Water soluble $\mathrm{P}_{2} \mathrm{O}_{5}$ & \multirow{2}{*}{$\begin{array}{c}\text { Water soluble } \mathrm{P}_{2} \mathrm{O}_{5} \\
---\% \text { total } \mathrm{P}_{2} \mathrm{O}_{5}^{---}\end{array}$} \\
\hline & \multicolumn{2}{|c|}{--------------------------------------\%"------------------------------------- } & \\
\hline TSP & $49.9 \pm 1.2$ & $35.5 \pm 2.7$ & 71 \\
\hline $\mathrm{TSP}_{-} \mathrm{WS}_{350}$ & $31.6 \pm 2.5$ & $26.4 \pm 0.2$ & 83 \\
\hline TSP-WS $_{700}$ & $30.1 \pm 0.3$ & $25.0 \pm 0.3$ & 83 \\
\hline TSP-SB $_{350}$ & $31.4 \pm 0.6$ & $25.6 \pm 0.8$ & 82 \\
\hline TSP-SB 700 & $29.3 \pm 1.3$ & $24.5 \pm 0.2$ & 84 \\
\hline
\end{tabular}

Values are mean $(n=3) \pm$ standard deviation.

There was no significant interaction $(\mathrm{p}<0.05)$ between the studied factors (rate and source of $\mathrm{P}$ ) for the studied variables. Thus, each factor was studied individually. The maize dry matter yield (DMY) was higher in the first crop when compared to the second crop (Figure 2B), probably because of the higher availability of $P$ in the first crop, since $P$ was not reapplied in the second crop using only the residual effect of the first application. In addition, the cultivation season may have influenced the DMY, since the second cultivation was carried out in April and May 2015, when the temperature was lower as compared to the first crop cycle (February and March 2015). In the first crop, maize DMY was lower at $100 \mathrm{mg}$ $\mathrm{dm}^{-3}$ as compared to 200 and $400 \mathrm{mg} \mathrm{dm}^{-3}$ (Figure 2A). In the second crop, as the $\mathrm{P}$ dose increased, there was an increase in maize DMY, probably due to the greater residual effect provided by the increase in the $\mathrm{P}$ rate. Regarding the $P$ sources, there was no difference $(p<0.05)$ on DMY for the TSP fertilizer with any of the treatments using the granulated biochars. The DMY for the control treatment (without $\mathrm{P}$ ) was 1.5 and $1.0 \mathrm{~g}$ in the first and second crops, respectively (data not shown).

The relative agronomic effectiveness (RAE) of the phosphate fertilizer associated with the biochars was higher (up to $100 \%$ ) when compared to TSP in most cases (Figure 3B). This effect was more pronounced in the second crop, which may be related to the effect of the biochars in providing better access to $\mathrm{P}$ by the plant (Blackwell et al., 2015). In a study with green peppers, researchers observed increases in productivity up to $20 \%$ with the use of fertilizers 
associated with biochar in relation to conventional fertilizers (Yao et al., 2015). However, these authors used a mixture of biochar + soluble nutrient sources + bentonite, which promoted slower release and provided better use of the nutrients by the plants, influencing even on the quality of the pepper with increase in the content of vitamin $\mathrm{C}$. The RAE differed $(\mathrm{p}<0.05)$ for the doses in both crops (Figure 3A). In the first crop, the doses $100 \mathrm{mg} \mathrm{dm}^{-3}$ and $400 \mathrm{mg} \mathrm{dm}^{-3}$ were higher. In the second crop, the application of $100 \mathrm{mg}$ $\mathrm{dm}^{-3}$ presented higher RAE when compared to the doses of 200 and $400 \mathrm{mg} \mathrm{dm}^{-3}$. Other studies have reported that an increase in $\mathrm{P}$ fertilizer rates may lead to a significant reduction of RAE (Chagas et al., 2016; Fageria; Baligar, 2014).

Soil-available P, after two successive maize crops by the Mehlich-1 extractor, increased according to the applied P dose (Figure 4A). Among the sources, TSP-WS ${ }_{350}$ showed $21.3 \%$ higher available $\mathrm{P}$ content when compared to TSP (Figure 4B). The phosphate fertilizers associated with biochars, despite having water-extractable $\mathrm{P}$ greater than TSP, allowed an increase of P available after two successive maize crops. According to Jiang et al. (2015), the anionic
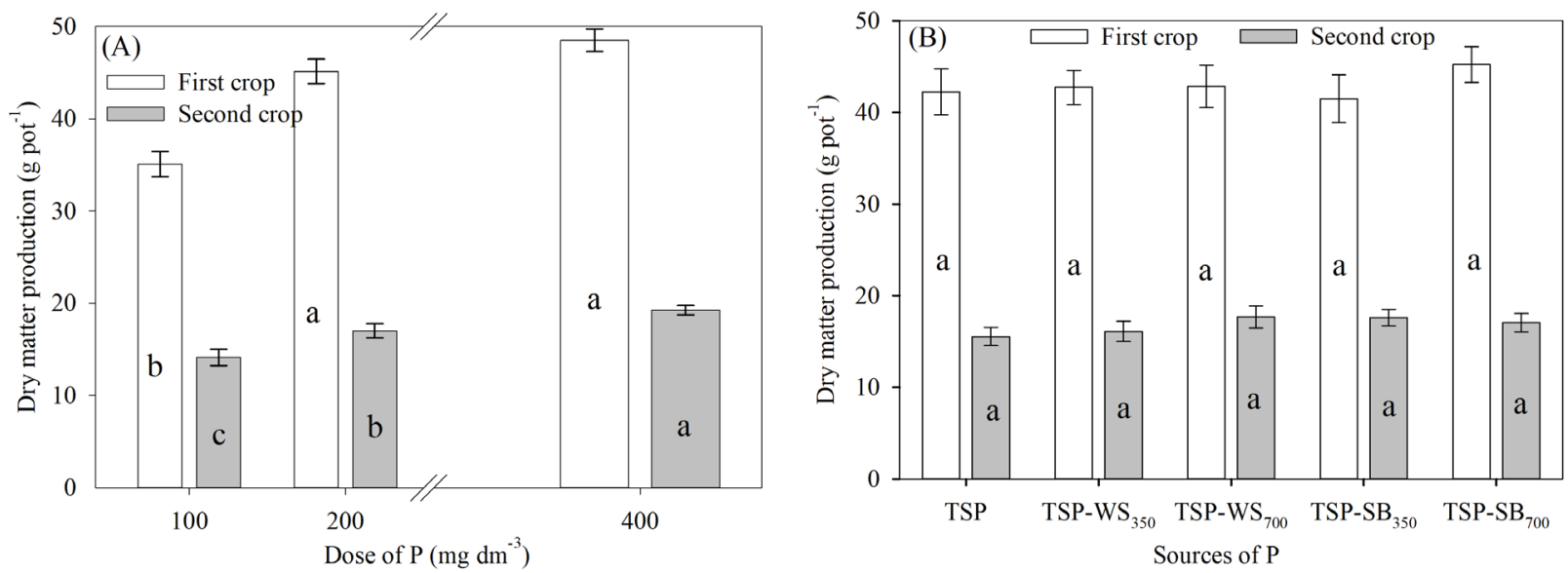

Figure 2: Effect of doses (A) and sources (B) of $P$ on the production of dry matter in two successive maize crops. Vertical bars (I) represent the standard error with 4 replications. Different letters in the column for each cultivation indicates significant difference at $p \leq 0.05$ by the Tukey test.
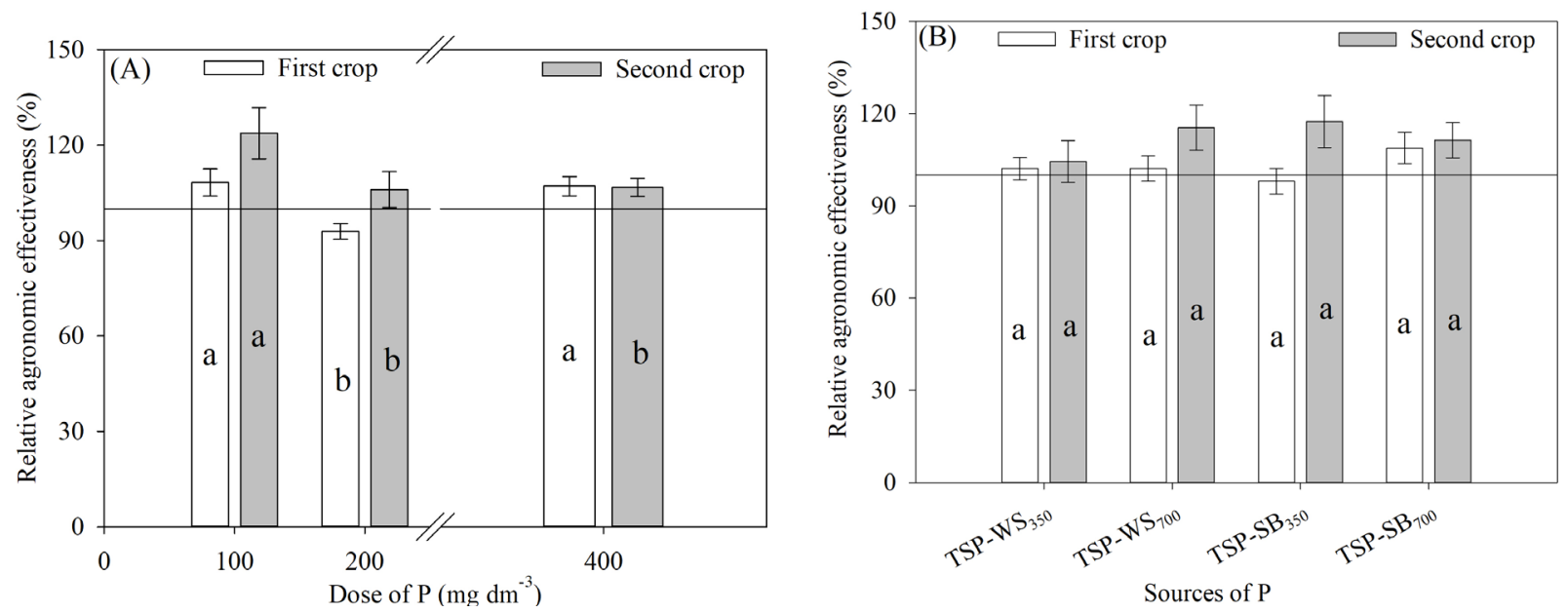

Figure 3: Effect of doses (A) and sources (B) of $P$ on the relative agronomic effectiveness of fertilizers associated with biochar in maize cultivation. The horizontal solid line represents the efficiency of triple superphosphate (100\%). Vertical bars (I) represent the standard error with 4 replications. Different letters in the column for each cultivation indicate significant difference at $p \leq 0.05$ by the Tukey test. 
functional groups of the biochar generate CEC, which compete with $\mathrm{P}$ by the sorption sites in the soil increasing $P$ availability.. In addition, biochar application to soils may increase the soil CEC due to the liming effect, which also increase P availability (Jiang et al., 2015). In this study, the liming effect was likely the cause of slightly increasing P availability in the soil, since the CEC of the biochars were low, especially in the WS biochars (Table 2).

The total P uptake by maize were significantly affected by the applied doses, being the highest averages observed in both cultivations at the dose of $400 \mathrm{mg} \mathrm{dm}^{-3}$ (Figure 5A). The uptake of $\mathrm{P}$ by maize was directly proportional to DMY. As for DMY, there was greater $\mathrm{P}$ uptake in the first crop. Among the sources, the first crop had an adequate supply of $\mathrm{P}$ causing no difference in $\mathrm{P}$ uptake (Figure 5B). However, in the second crop, there was higher $\mathrm{P}$ uptake in plants fertilized with the sources TSP$\mathrm{WS}_{700}$ and TSP-SB ${ }_{350}$ when compared to TSP. A higher P uptake in plants fertilized with TSP-WS ${ }_{700}$ and TSP-SB ${ }_{350}$ increased DMY to $13.7 \%$ and $13.4 \%$, respectively, when compared to TSP. It is likely that biochar is protecting $\mathrm{P}$ from soil sorption and making it more available to plants over time. This is evidenced by the higher uptake of $\mathrm{P}$ by maize plants in the second crop and higher soil available $\mathrm{P}$ after two successive maize crops.

The recovery rate (RR) of $\mathrm{P}$ by maize plants followed the inverse trend of $\mathrm{P}$ uptake; the higher the dose the lower the RR by maize (Figure 6A). This effect occurred because the plant absorbs only a small part of the applied P. Thus, at the dose of $100 \mathrm{mg} \mathrm{dm}^{-3}$, RR was higher when compared to the proportional $\mathrm{P}$ applied at the doses of 200 and $400 \mathrm{mg} \mathrm{dm}^{-3}$. There was no statistical difference between the sources for RR (Figure 6B). The TSP-SB ${ }_{350}$ and TSP-SB ${ }_{750}$ sources presented the highest $\mathrm{RR}$, mainly in the second crop, indicating that this fertilizer provided greater access to $\mathrm{P}$ when compared to TSP. These results show that the effects of biochar in the availability, acquisition, and use of $\mathrm{P}$ by the plant should be more significant under conditions of low P availability, such as the residual effect of $\mathrm{P}$ fertilization on the second maize crop observed in this study. Furthermore, it should be noticed that the biochar associated with the fertilizer granule might not regulate the availability but act as an attenuator of $P$ release in the soil.

Using another approach, Lustosa Filho et al. (2017) co-pyrolysed poultry litter with phosphate sources, including TSP. These authors showed a much slower $P$ release rate as compared to TSP and also a similar maize yield in a pot experiment. Additionally, Carneiro et al. (2018) observed that co-pyrolysis of biomass with phosphate sources increased the yield of biochar and also increased the carbon retention during pyrolysis and carbon chemical and thermal stability. Future studies should be focused on testing novel binding agents during the granulation process, which can control the release behavior of $\mathrm{P}$ over time favoring the $\mathrm{P}$ uptake by the plant throughout the cultivation, thus improving the efficiency of use of soluble-P fertilizers.
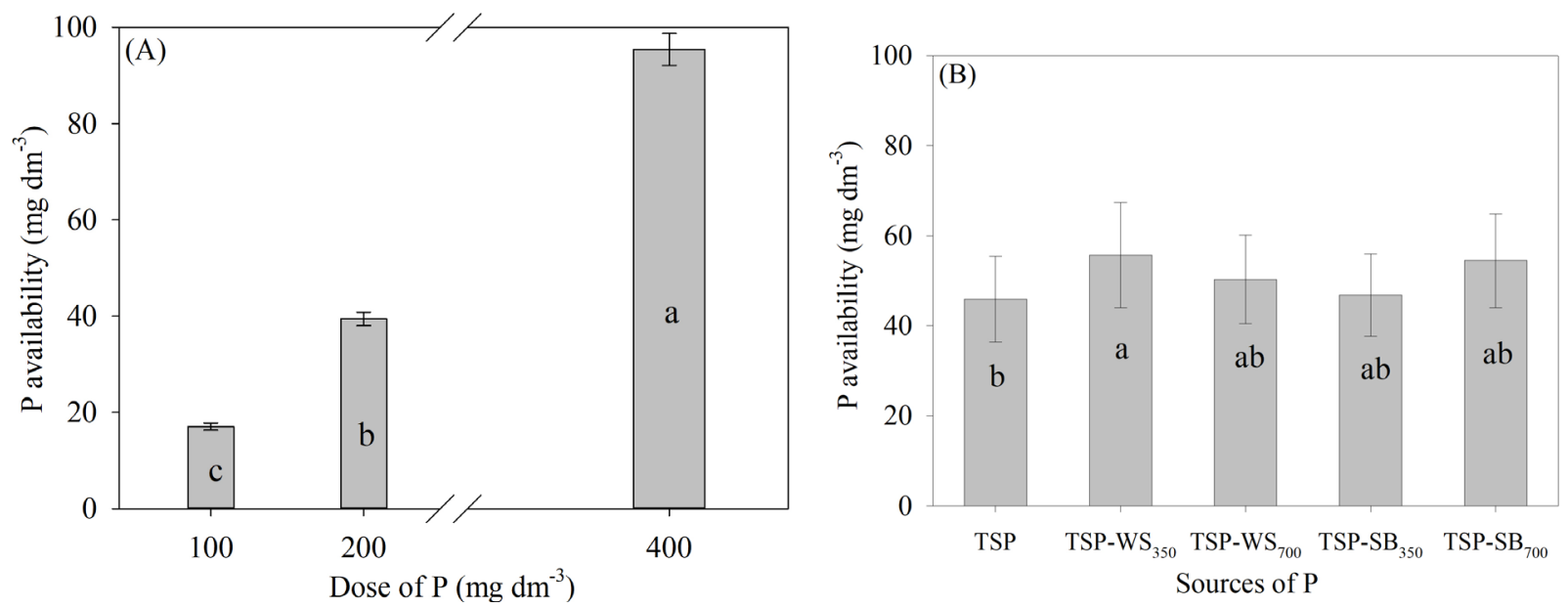

Figure 4: Phosphorus available in the soil by the Mehlich-1 extractor as a function of the application of doses (A) and sources (B) of phosphate fertilizers after two successive maize crops. Vertical bars (I) represent the standard error with 4 replications. Different letters in the columns indicate significant difference at $p \leq 0.05$ by the Tukey test. 

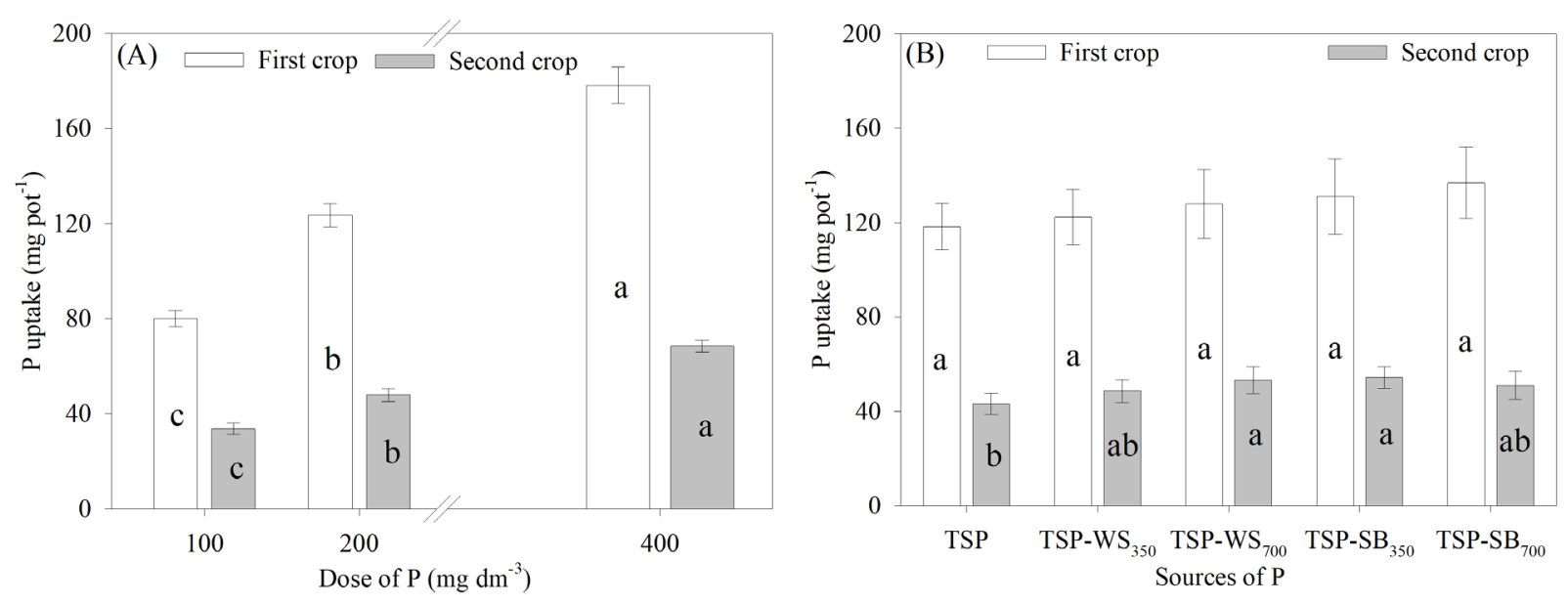

Figure 5: Maize $P$ uptake as a function of doses $(A)$ and sources $(B)$ of phosphate fertilizers in two successive crops. Vertical bars (I) represent the standard error with 4 replications. Different letters in the column for each cultivation indicate significant difference at $p \leq 0.05$ by the Tukey test.
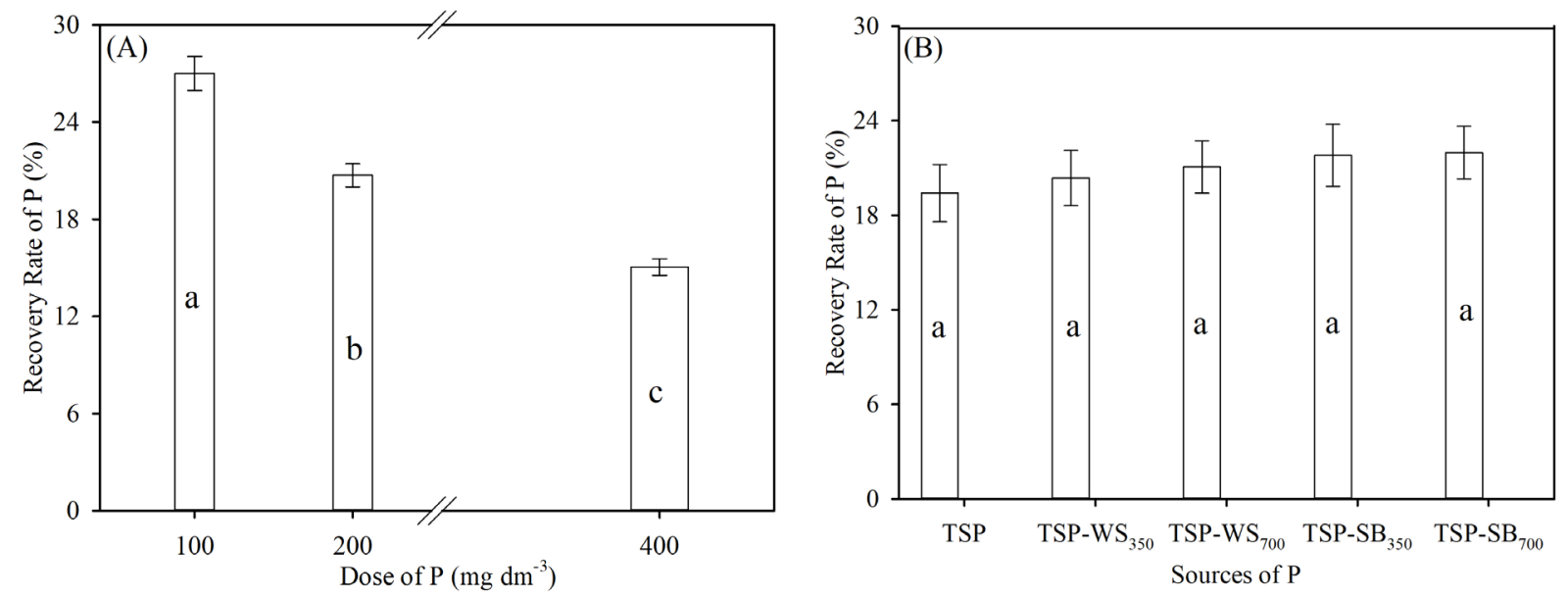

Figure 6: Recovery rate of $P$ (sum of both crops) in maize crop as a function of doses (A) and $P(B)$ sources of phosphate fertilizers. Vertical bars (I) represent the standard error with 4 replications. Different letters in the column indicate significant difference at $p \leq 0.05$ by the Tukey test.

\section{CONCLUSIONS}

The hypothesis raised in this study has not been proven and, in general, the simple association of soluble phosphate fertilizer (TSP) with the biochars did not increase the efficiency of $P$ use by maize cultivated in a clayey soil with high P-fixing capacity. Nevertheless, it increased available $P$ in soil after two successive crops. This implies that other strategies should be adopted in order to reduce P fixation applied via fertilizer in soil and to increase the uptake and utilization of $\mathrm{P}$ by plants.

\section{REFERENCES}

ABDALA, D. B. et al. Long-term manure application effects on phosphorus speciation, kinetics and distribution in highly weathered agricultural soils. Chemosphere, 119:504-514, 2015.

AHMEDNA, M. et al. Potential of agricultural by-product-based activated carbons foar use in raw sugar decolourisation. Journal of the Science of Food and Agriculture, 75(1):117-124, 1997.

ALVAREZ V. V. H. et al. Determinação e uso do fósforo remanescente. Boletim Informativo, 25(1):27-33, 2000. 
AMERICAN SOCIETY FOR TESTING AND MATERIAL - ASTM. Standard Test Method for Chemical. Analysis of Wood Charcoal. D 1762-84. West Conshohocken, PA: ASTM International, 2007. Available in: http://https://www. astm.org/Standards/D1762.htm. Access in: November, 26, 2014.

BLACKWELL, P. et al. Influences of biochar and biochar-mineral complex on mycorrhizal colonisation and nutrition of wheat and sorghum, Pedosphere, 25(5):686-695, 2015.

BOLAN, N. S.; BARROW, N. J.; POSNER, A. M. Describing the effect of time on sorption of phosphate by iron and aluminium hydroxides. Journal of Soil Science, 36(2):187197, 1985.

BRAGA, J. M.; DEFELIPO, B. V. Determinação espectrofotométrica de fósforo em extratos de solos e plantas. Revista Ceres, 21(113):73-85, 1974.

BRASIL. Ministério da Agricultura, Pecuária e Abastecimento. Manual de métodos analíticos oficiais para fertilizantes e corretivos. Brasília- DF: Murilo Carlos Muniz Veras (Org.). MAPA/SDA/CGAL, 2014. 230p.

CANTRELL, K. B. et al. Impact of pyrolysis temperature and manure source on physicochemical characteristics of biochar. Bioresource Technology, 107:419-428, 2012.

CARNEIRO, J. S. S. et al. Carbon stability of engineered biocharbased phosphate fertilizers. ACS Sustainable Chemistry \& Engineering, 6(11):14203-14212, 2018.

CHAGAS, W. F. T. et al. Agronomic efficiency of polymer-coated triple superphosphate in onion cultivated in contrasting texture soils. Revista Ciência Agronômica, 47(3):439446, 2016.

CHIEN, S. H.; PROCHNOW, L. I.; CANTARELLA, H. Recent developments of fertilizer production and use to improve nutrient efficiency and minimize environmental impacts. Advances in Agronomy, 102(9):267-322, 2009.

CHOWDHURY, Z. Z. et al. Influence of carbonization temperature on physicochemical properties of biochar derived from slow pyrolysis of durian wood (Durio zibethinus) sawdust. BioResources, 11(2):3356-3372, 2016.

CORDELL, D.; DRANGERT, J. O.; WHITE, S. The story of phosphorus: Global food security and food for thought. Global Environmental Change, 19(2):292-305, 2009.

CUI, H. J. et al. Enhancing phosphorus availability in phosphorusfertilized zones by reducing phosphate adsorbed on ferrihydrite using rice straw-derived biochar. Journal of Soils and Sediments, 11(7):1135-1141, 2011.
DOMINGUES, R. R. et al. Properties of biochar derived from wood and high-nutrient biomasses with the aim of agronomic and environmental benefits. PLOS ONE, 12(5):1-19, 2017.

DONAGEMA, G. K. et al (org.). Manual de métodos de análise de solo. 2 ed. Rio de Janeiro: Embrapa Solos, 230p. 2011. (Embrapa Solos. Documentos, 132).

ERRO, J. et al. Incorporation of humic-derived active molecules into compound NPK granulated fertilizers: Main technical difficulties and potential solutions. Chemical and Biological Technologies in Agriculture, 3(18):1-15, 2016.

FAGERIA, N. K.; BALIGAR, V. C. Macronutrient-use efficiency and changes in chemical properties of an oxisol as influenced by phosphorus fertilization and tropical cover crops. Communications in Soil Science and Plant Analysis, 45(9):1227-1246, 2014.

FERREIRA, D. F. Sisvar: A Guide for its Bootstrap procedures in multiple comparisons. Ciência e Agrotecnologia, 38(2):109-112, 2014.

GASKIN, J. W. et al. Effect of low-temperature pyrolysis conditions on biochar for agricultural use. Transactions of the ASABE, 51(6):2061-2069, 2008.

GHANI, W. A. W. A. K. et al. Biochar production from waste rubber-wood- sawdust and its potential use in $C$ sequestration: Chemical and physical characterization, Industrial Crops and Products, 44:18-24, 2013.

GLASER, B. et al. Biochar organic fertilizers from natural resources as substitute for mineral fertilizers. Agronomy for Sustainable Development, 35(2):667-678, 2015.

GUELFI, D. R. et al. Monoammonium phosphate coated with polymers and magnesium for coffee plants. Ciência e Agrotecnologia, 42(3):261-270, 2018.

JIANG, J. et al. Mobilization of phosphate in variable-charge soils amended with biochars derived from crop straws. Soil and Tillage Research, 146:139-147, 2015.

KANG, J. et al. Phosphorus leaching in a sandy soil as affected by organic and inorganic fertilizer sources. Geoderma, 161 (3-4):194-201, 2011.

KIM, P.; HENSLEY, D.; LABBÉ, N. Nutrient release from switchgrass-derived biochar pellets embedded with fertilizers. Geoderma, 232-234:341-351, 2014.

LEHMANN, J.; GAUNT, J.; RONDON, M. Bio-char sequestration in terrestrial ecosystems - A review. Mitigation and Adaptation Strategies for Global Change, 11:403-427, 2006. 
LEHMANN, J.; STEPHEN, J. Biochar for environmental management: Science, technology and implementation. 2nd ed. London: Routledge, 2015. 944p.

$\mathrm{LI}, \mathrm{H}$. et al. Mechanisms of metal sorption by biochars: Biochar characteristics and modifications. Chemosphere, 178:466478, 2017.

LIU, X. et al. Biochars effect on crop productivity and the dependence on experimental conditionsa meta-analysis of literature data. Plant and Soil, 373(1-2):583-594, 2013.

LUSTOSA FILHO, J. F. et al. Co-pyrolysis of poultry litter and phosphate and magnesium generates alternative slow release fertilizer suitable for tropical soils. ACS Sustainable Chemistry \& Engineering, 5(10):9043-9052, 2017.

MALAVOLTA, E.; VITTI, G. C.; OLIVEIRA, S. A. Avaliação do estado nutricional das plantas: Princípios e aplicações. 2 ed. Piracicaba: Potafos, 1997. 319p.

MELO, L. C. A. et al. Influence of pyrolysis temperature on cadmium and zinc sorption capacity of sugar cane straw - derived biochar. BioResources, 8(4):4992-5004, 2013.

MILLER, R. O. High-Temperature Oxidation: Dry Ashing. In: KALRA, Y. P. Handbook of reference in methods for plantas analysis. New York: CRC Press, 1998. p.53-56.

NOVAIS, R. F.; NEVES, J. C. L.; BARROS, N. F. Ensaio em ambiente controlado. In: OLIVEIRA, A. J. et al. (Eds.). Métodos de pesquisa em fertilidade do solo. Brasília: Embrapa-SEA, 1991. p.189-253.

NOVAIS, R. F.; SMYTH, T. J. Fósforo em solo e planta em condições tropicais. Viçosa: Universidade Federal de Viçosa, 1999. 399p.

PARVAGE, M. M. et al. Phosphorus availability in soils amended with wheat residue char. Biology and Fertility of Soils, 49(2):245-250, 2013.

PHINICHKA, N.; KAENTHONG, S. Regenerated cellulose from high alpha cellulose pulp of steam-exploded sugarcane bagasse. Journal of Materials Research and Technology, 7(1):55-65, 2017.
PLACIDO, J.; CAPAREDA, S.; KARTHIKEYAN, R. Production of humic substances from cotton stalks biochar by fungal treatment with Ceriporiopsis subvermispora. Sustainable Energy Technologies and Assessments, 13:31-37, 2016.

SANDERS, J. L. et al. Improving phosphorus use efficiency with polymer technology. Procedia Engineering, 46:178-184, 2012.

SINGH, B.; SINGH, B. P.; COWIE, A. L. Characterisation and evaluation of biochars for their application as a soil amendment. Australian Journal of Soil Research, 48(7):516-525, 2010.

SONG, W.; GUO, M. Quality variations of poultry litter biochar generated at different pyrolysis temperatures. Journal of Analytical and Applied Pyrolysis, 94:138$145,2012$.

SYERS, J. K.; JOHNSTON, A. E.; CURTIN, D. Efficiency of soil and fertilizer phosphorus use: Reconciling changing concepts of soil phosphorus behaviour with agronomic information. Rome: Food and Agricultural Organization of the United Nations, 2008. 108 p.

VENEKLAAS, E. J. et al. Opportunities for improving phosphorususe efficiency in crop plants. New Phytologist, 195(2):306320, 2012.

WU, W. et al. Chemical characterization of rice straw-derived biochar for soil amendment. Biomass and Bioenergy, 47:268-276, 2012.

YAO, C. et al. Developing more effective enhanced biochar fertilisers for improvement of pepper yield and quality. Pedosphere, 25(5):703-712, 2015.

YUAN, J. H.; XU, R. K.; ZANG H. The forms of alkalis in the biochar produced from crop residues at different temperatures. Bioresource Technology, 102:3488-3497, 2011.

ZHAl, L. et al. Short-term effects of maize residue biochar on phosphorus availability in two soils with different phosphorus sorption capacities. Biology and Fertility of Soils, 51(1):113-122, 2015. 